American University Washington College of Law

Digital Commons @ American University Washington College of

Law

Articles in Law Reviews \& Other Academic Journals

Scholarship \& Research

1995

Bankruptcy in Russia: The Evolution of a Comprehensive Russian Bankruptcy Code

Paul Williams

Paul Wade

Follow this and additional works at: https://digitalcommons.wcl.american.edu/facsch_lawrev

Part of the Bankruptcy Law Commons, Comparative and Foreign Law Commons, Law and Economics Commons, and the Legislation Commons 


\title{
BANKRUPTCY IN RUSSIA: THE EVOLUTION OF A COMPREHENSIVE RUSSIAN BANKRUPTCY CODE
}

\author{
Paul R. Williams* \\ Paul E. Wade**
}

When Mikhail Gorbachev began the restructuring reforms of perestroika, he envisioned creating a "market-based" economy within the Soviet political system. With the dissolution of the Soviet Union in 1991, the reforms originating from perestroika were accelerated as market-oriented policy makers took advantage of the temporary disappearance of the communist party and the emerging tide of public opinion favoring market reform. However, despite their early enthusiasm to embrace market reform, President El'tsin and many other supporters of the move to a market-based economy have shown a reluctance to consider the possibility of bankruptcy, one perceived down-side of a truly free market. ${ }^{1}$ Despite this reluctance, the Russian Parliament recently enacted a comprehensive bankruptcy code.

This article traces the development of the current bankruptcy code, with its origins in the early economic laws of perestroika; explains key provisions of the current law; and comments on the prospects for its effective implementation. The intent of this article is to provide a balanced understanding of the Russian bankruptcy code useful both to the study of the emergence of a market-based economy in Russia and as a bankruptcy primer for individuals or corporations conducting business in Russia.

* Fulbright Research Scholar, University of Cambridge, and Executive Director of the Public International Law and Policy Group; J.D., Stanford Law School, 1990; B.A., University of California, Davis, 1987. Attorney-Adviser, Office of the Legal Adviser for European and Canadian Affairs, United States Department of State, 1991-1993.

** M.A. Russian and East European Studies, University of Kansas, 1994; B.A., United States Air Force Academy, 1987. Mr. Wade is currently an active duty Captain in the United States Air Force.

The authors are greatly indebted to Professor John Garland of the University of Kansas School of Business for his many helpful comments and suggestions during the writing of this article. The opinions expressed in this article are those of the authors and do not necessarily reflect the views of the U.S. Government.

1. President El'tsin's economic strategy can be characterized as a balance between the pursuit of the most rapid transition to a market economy possible and the desire to avoid losing public support for market reform, including the support of key public and military figures. 


\section{Evolution of the Concept of Bankruptcy During the Market Reforms of Perestroika}

The development of Russian laws relating to bankruptcy has been erratic and occasionally contradictory. Economic laws passed during the early phases of perestroika appear to mention bankruptcy as an afterthought, included simply because it is a characteristic of a free market. ${ }^{2}$ As the difficulties of moving to a market-based economy began to materialize in the later years of perestroika, the new economic laws received greater scrutiny, and the concept of bankruptcy in Russia began to take form around the five basic functions of bankruptcy. The importance of resolving the issue of insolvent enterprises eventually led to lengthy legislation specifically covering bankruptcy. ${ }^{3}$

In order to trace the development of bankruptcy law in Russia, this article will briefly identify major Soviet or Russian legislation containing provisions addressing bankruptcy, and then explore the evolution in Soviet and Russian law of the five functions of a rudimentary bankruptcy code: defining bankruptcy, determining insolvency, establishing a process for reorganization or liquidation, establishing creditors' rights and priority, and discharging debt obligations.

\subsection{Chronology}

The Law on State Enterprises adopted on 30 June 1987 represents an early attempt to reform the Soviet economy ${ }^{4}$ and, although marking a major move toward the establishment of a market-based economy, the law reflects a number of misconceptions concerning the operation of a market-economy, particularly in the area of bankruptcy. The 1988 Law on Cooperatives in the USSR, adopted primarily to regulate the evolving nature of cooperative enterprises, dealt briefly with the bankruptcy of such enterprises. ${ }^{5}$ The Law on Enterprises in the USSR adopted on 4 June 1990 represented the first

2. The concept of bankruptcy was generally disregarded in pre-perestroika legislation as the Soviet law-makers believed that since the planned economy excludes most trading risks, insolvency would not be a legal problem. A.K.R. Kiralfy, "Insolvency", Encyclopedia of Soviet Law at 321 (1973). See also C. Osakwe, Soviet Business Law at 12-9 (1992) (In a system where all major means of production and distribution are owned by the state, the principle of bankruptcy should not be given prominence.)

3. The last few years have witnessed a steady jettisoning of socialist rhetoric and a continuing refinement of Russian treatment of the concept of bankruptcy.

4. Law on State Enterprises, 27 Soviet Statutes \& Decisions 6 (Summer 1990) [hereinafter Law on State Enterprises].

5. Law on Cooperatives in the USSR, 26 Soviet Statutes \& Decisions 65 (Winter 1989-90) [hereinafter Law on Cooperatives]. 
attempt at a bankruptcy code, constrained, however, by substantial reliance on the principles of a state economy. ${ }^{6}$ In the months immediately preceding the failed coup of August 1991, the Supreme Soviet enacted the Fundamental Principles of Civil Legislation of the USSR and Republics, which attempted to establish a refined legal framework for the genesis of a market-based economy. ${ }^{7}$

In addition to this Soviet legislation, Russia enacted two significant pieces of legislation on 25 December 1990, prior to the dissolution of the Soviet Union. The Russian Law on Enterprises and Entrepreneurial Activity attempted to accelerate the establishment of a general bankruptcy code in Russia, ${ }^{8}$ while the Statute on Joint-Stock Companies established preliminary bankruptcy procedures for joint-stock companies. ${ }^{9}$

\subsection{Functions of a Bankruptcy Code}

The legislation enacted by the Soviet Union and Russia initiated the process of shifting the Soviet economy from a command to a market-based economy. The following examination of the evolution of the five basic functions of a bankruptcy code indicates the uncertainty with which the law-makers launched this shift. Although some of the shortcomings of early bankruptcy-related legislation may have their origin in either a reluctance to shift to a marketbased economy, or an unawareness of the need for a bankruptcy code and its necessary content, these shortcomings are important as a market-based economy can only operate effectively when complemented by an operative bankruptcy system. ${ }^{10} \mathrm{~A}$ bankruptcy code will only engender an operative bankruptcy system if it establishes an adequate legal foundation for the five primary functions of bankruptcy.

6. Law on Enterprises in the USSR, 29 Soviet Statutes \& Decisions 81-82 (Winter 1990-91) [hereinafter Law On Enterprises].

7. Fundamental Principles of Civil Legislation of the USSR and Republics, 1992 Basic Documents on the Soviet Legal System 104-5 (1992). The Fundamental Principles of Civil Legislation, although adopted prior to the dissolution of the former Soviet Union, were not due to take effect until 1 January 1992, by which time the Soviet Union had dissolved. "On the Introduction into Effect of the Fundamental Principles of Civil Legislation of the USSR and Republics", 1992 Basic Documents on the Soviet Legal System 177 (1992).

8. Law on Enterprises and Entrepreneurial Activity, 1992 Basic Legal Documents of the Russian Federation 192 (1992) [hereinafter Russian Law on Enterprises].

9. Statute on Joint-Stock Companies, 1992 Basic Legal Documents of the Russian Federation 223 (1992) [hereinafter Statute on Joint-Stock Companies].

10. The primary purpose of bankruptcy is to keep resources active in a market-economy. Capital is kept active by allowing creditors to liquidate a bankrupt enterprise and thereby retrieve as much of their capital as possible, letting the creditors then reinvest that capital in another enterprise. Human capital is kept active by permitting an honest debtor to be relieved of onerous debt, and start a new enterprise without carrying over the debt burden from the previous enterprise. 


\section{Defining Bankruptcy}

The first function of a bankruptcy code is to define what constitutes a bankrupt enterprise. A bankrupt enterprise is generally an enterprise which is insolvent. Insolvency occurs either when 1) the enterprise has debts in excess of assets, or 2) the enterprise is unable to pay its debts as they mature.

The Law on State Enterprises defined bankruptcy as a systematic violation of "payments discipline." "I The Law on Cooperatives provided that a cooperative may be deemed insolvent if it "repeatedly fails to make payments." 2 The Russian Law on Enterprises provided that an enterprise may be declared bankrupt "in the event it is impossible [for the enterprise] to perform obligations to creditors." 13 The Fundamental Principles of Civil Legislation, although not defining bankruptcy, did define the concept of a legal person, ${ }^{14}$ hitherto undefined, and provided that a legal person could be liquidated by a decision of a court in the event of bankruptcy. ${ }^{15}$

Although designed to spur a move to a market-based economy, these early attempts to define the concept of bankruptcy relied heavily upon the staid concept of a centrally planned economy to administer the free market. ${ }^{16}$ The definitions of profitability and bankruptcy were the result of a wish to direct profitability rather than define it, and as such were more akin to aspirational standards rather than rules that could be applied through administrative determinations. As a result of their vague nature, such standards could be manipulated in a highly discretionary manner and were of little use as a building-block for establishing a comprehensive system of bankruptcy useful for the operation of a market-based economy.

\section{Determining Insolvency}

After defining bankruptcy, a bankruptcy code must set forth a procedure for determining whether an enterprise is insolvent. The two primary aspects of a bankruptcy code relating to a determination of insolvency are: 1) which state institution is capable of declaring an enterprise insolvent, and 2) what

11. Law on State Enterprises, supra note 4, art. 18, sec. 3, at 59. The Law on State Enterprises requires all enterprises to function without showing a loss and that, in the case of temporary "planned-loss operations," the enterprise be financed by the "higher-level agency" responsible for the section of the economy in which the industry was located. Id. art. 17, sec. 4 , at 56.

12. Law on Cooperatives, supra note 5 , art. 23, sec. 3, at 65 .

13. Russian Law on Enterprises, supra note 8, art. 17, at 192.

14. A legal person is defined as "an organization which has discrete property in ownership, full economic jurisdiction, or operative management, is liable for its obligations with such property, and appears in a court ... in its own name." Fundamental Principles of Civil Legislation, supra note 7, art. 11, para. 1, at 104-5.

15. Id. art. 17, para. 1 , at 107 .

16. This is most clearly indicated by the reliance upon the higher-level agency to fund shortterm losses of the enterprise. 
procedure must that institution follow before it may make such a declaration?

The Law on State Enterprises granted creditor banks the power to declare an enterprise insolvent in cases of a systematic violation of payments discipline. ${ }^{17}$ The bank was then required to report this declaration to the basic suppliers of goods and materials to the enterprise, and to a higher-level agency.$^{18}$ The Law on State Enterprises also provided that in the event an enterprise operated at a loss for a substantial time period despite taking measures to remain solvent, the agency empowered to create the enterprise could terminate the enterprise. ${ }^{19}$ An enterprise could therefore be declared insolvent by either a creditor bank, or the state agency responsible for the enterprise.

The Law on Cooperatives placed the power of determining bankruptcy for purposes of reorganizing payment schedules with the banks, and for purposes of liquidation with the local soviet of peoples' deputies upon the request of the creditor bank. ${ }^{20}$ The Law on Cooperatives did not, however, create a procedure for making a determination of insolvency. ${ }^{21}$ The Law on Enterprises departed from earlier practice and permitted liquidation of an enterprise upon decision of a court, and provided for voluntary as well as involuntary bankruptcy. ${ }^{22}$ The Russian Law on Enterprises adopted the practice of placing responsibility for bankruptcy determination with the courts. ${ }^{23}$

Removing the power to determine insolvencies from the jurisdiction of the central bank and local soviets (instruments of a planned economy), and placing that responsibility with the court system (instrument of a democratic/ market-based regime) marked an important realization that bankruptcies involve a balancing of interests both between the debtor and creditor(s), and amongst creditors. Similarly, the distinction between voluntary and involuntary bankruptcies recognized that there may be a variety of motivations for declaring bankruptcy. Unfortunately, up to this point there was no consideration of what procedure a court should follow in order to ensure an impartial process, balance the interests of the parties, and prevent misuse of a bankruptcy regime.

17. Law on State Enterprises, supra note 4, art. 18, sec. 3, at 59.

18. Id.

19. Id. art. 23 , at 65 .

20. Law on Cooperatives, supra note 5 , art. 23 , sec. 3 , at 65 .

21. Id.

22. Law on Enterprises, supra note 6, at 81.

23. Russian Law on Enterprises, supra note 8, art. 17, at 192. 


\section{Establishing a Process for Reorganization or Liquidation}

After an enterprise is declared insolvent, following the proper procedure, the institution responsible for making such a declaration must establish either a process for reorganizing the enterprise so that is may become profitable again, ${ }^{24}$ or a process for liquidating the enterprise and allocating its assets amongst its creditors. ${ }^{25}$

The Law on State Enterprises provided that in the event of short-term losses, an enterprise must "work out measures to strengthen its financial position, to eliminate the unprofitable production of output (work, services) within an established time period, and to ensure operation at a profit." ${ }^{26}$ The Law on Cooperatives provided that the bank declaring the cooperative insolvent "will determine the cooperative's payment schedule until it is restored to financial health. ${ }^{2}{ }^{27}$ In the event the cooperative regularly registered losses, as noted above, the bank could request the local soviet of peoples' deputies to liquidate the cooperative. ${ }^{28}$

The Law on Enterprises provided that "an enterprise shall be liquidated ... when it is declared to be bankrupt." ${ }^{.29}$ In the event of voluntary liquidation, the liquidation would be carried out by a liquidation commission, and in the case of involuntary liquidation, by the court. ${ }^{30}$ The owner or court was responsible for establishing "the procedure and the timetable for the liquidation, as well as [the] time period during which creditors may present their claims." ${ }^{31}$ The Russian Law on Enterprises, ${ }^{32}$ and the Statute on Joint-Stock Companies ${ }^{33}$ mirrored the Law on Enterprises with respect to declarations of bankruptcy, and procedures for liquidation. The Statute provided a more detailed description of the duties of the commission responsible for liquida-

24. A reorganization entails the temporary suspension of creditors' claims for a period of time in which the debtor is provided the opportunity to reorganize his operations. The intent of reorganization is to relieve the debtor's debt burden and provide an opportunity to reestablish the solvency of the enterprise. If the reorganization is successful, the creditors' claims will then be paid out of the post-bankruptcy earnings of the debtor pursuant to a schedule approved by the institution administering the bankruptcy.

25. The process of liquidation entails 1) the collection of the assets by a trustee, appointed by the institution presiding over the bankruptcy, 2) the sale of those assets, 3) the distribution of the proceeds of the sale to the creditors of the enterprise, and 4) the discharge of the debtor from liability for pre-bankruptcy debts.

26. Law on State Enterprises, supra note 4, at 56.

27. Law on Cooperatives, supra note 5, art. 23, sec. 3, at 65.

28. Id.

29. Law on Enterprises, supra note 6, art. 37, at 81.

30. Law on Enterprises, supra note 6, art. 38, at 82-3.

31. Id. art. 38, at 82-3. This time period may not be less than two months.

32. Russian Law on Enterprises, supra note 8, arts. 37 \& 38, at 203-4.

33. Statute on Joint-Stock Companies, supra note 9, arts. $136 \& 137$, at 223. 
tion, including the appraisal of assets, solicitation of the creditors, and settlement of accounts. ${ }^{34}$

The evolution of these laws represents the waning influence of the centrally planned economy, where enterprises are not expected or permitted to become bankrupt, and the development of the embryonic stages of an effective process for liquidating bankrupt enterprises. Although recognizing the essential duties of bankruptcy administration, they did not fully recognize the concept of a structured reorganization, nor did they enunciate the necessary procedures for carrying out an effective reorganization or liquidation.

\section{Establishing Creditors ' Rights and Priority}

During the process of either reorganization or liquidation, a primary aim of the bankruptcy proceeding is to provide a means for ensuring that creditors receive the maximum repayment possible of their outstanding claims against the debtor enterprise. In the case of reorganization, bankruptcy proceedings, attempts to maximize repayment by staying competing creditor claims until the enterprise is restored to solvency at which time repayment will begin, or in the case of liquidation, converting and allocating the assets of the debtor in the most equitable manner. In order to ensure protection of the interests of creditors, a bankruptcy code must establish the rights of creditors to call for a bankruptcy and to participate in any bankruptcy proceedings. And, in order to assure an equitable allocation of assets, the bankruptcy code must establish the priority of payment amongst creditors.

The Law on State Enterprises provided that the bank declaring an enterprise insolvent was also responsible for determining the priority of creditor payments. ${ }^{35}$ Additionally, the law provided that citizens' claims and suits against the enterprise could be brought against the agency responsible for the creation of the enterprise. ${ }^{36}$ The Law on Cooperatives provided that when a cooperative was liquidated by the local soviet of peoples' deputies, "the claims of its creditors [would] be satisfied under the established procedures. ${ }^{37}$ The Law on Enterprises provided that creditors' claims would be satisfied out of the property of the enterprise, and established a class of

34. Id. art. 138 , at 223.

35. Law on State Enterprises, supra note 4, art. 18, sec. 3, at 59.

36. Id. art. 23 , sec. 2 , at 65 . This provision retained the aspect of the planned economy by extending responsibility for an enterprise to the "higher-level agency," which presumably still directed the operations of the enterprise.

37. Law on Cooperatives, supra note 5 , art. 23 , sec. 3 , at 65 . Although recognizing the need for determining priority of creditors, the law did not establish a priority or procedures, but referred to local procedures which likely did not exist. 
privileged creditors. ${ }^{38}$ Priority would first be given to "the satisfaction of debts to the budgets [of the State] and to the compensation of expenditures for the recultivation of lands that had been utilized by the liquidated enterprise. ${ }^{\prime 39}$ The Law on Enterprises also established the important principle of limiting liability of bankrupt enterprises to creditors by providing that "claims that have not been satisfied due to an insufficiency of property shall be considered to have been paid off." 40

The Russian Law on Enterprises replaced the privilege of state debt with an obligation to employees. This Law created a special class of employee creditors by declaring that the enterprise must "settle accounts fully with all workers of the enterprise according to the contracts concluded, irrespective of the financial state of the enterprise."41 The Fundamental Principles of Civil Legislation offered the first attempt at a detailed prioritization of a settling of accounts: payments in connection with harm to a citizen's health, payment of workers under labor contract, social insurance/security payments, and finally, payments to other creditors in accordance with legislative acts. ${ }^{42}$

Except for the Fundamental Principles of Civil Legislation, the prior acts evidence an experiment with the creation of various privileged creditors rather than an actual system of priority amongst creditors. The evolution away from the concept of a socialist economy toward a market-based economy is most apparent in this context - with the government first assigning priority to state debts, then switching to employee contracts, and then changing to a listing of creditors, with commercial creditors at the bottom of the list, but nevertheless on the list. Despite the final enunciation of a priority of creditors in the Fundamental Principles of Civil Legislation, there was as yet no actual consideration of the rights of creditors in the bankruptcy process.

\section{Discharging Debt Obligations}

The final function of bankruptcy is to relieve the honest debtors of oppressive debt and permit them to re-establish their business, or begin a new business without the continuation of pre-bankruptcy debts. An important function of a bankruptcy code is therefore to provide that debtors filing for

38. Law on Enterprises, supra note 6, art. 39, at 83.

39. Id.

40. Id. art. 39 , sec. 3 , at 83 .

41. Russian Law on Enterprises, supra note 8, at 191. This provision both creates a special class of privileged creditors and denies the real possibility that an enterprise will be unable to meet its contractual obligations toward its workers.

42. Fundamental Principles of Civil Legislation, supra note 7, art. 17, para. 2, at 108. No acts existed at the time of adoption indicating the priority of this last category of creditors. 
bankruptcy will receive some protection from creditors, either a short-term stay of debt payment obligations in the case of a reorganization or a discharge of debt obligations in the case of a liquidation.

The Law on Enterprises was the first act to discuss the discharge of debt obligations, providing that "claims that have not been satisfied due to an insufficiency of property shall be considered to have been paid off." ${ }^{.43}$ The Russian Law on Enterprises, however, required the entrepreneur to "settle accounts fully with all workers of the enterprise according to the contracts concluded, irrespective of the financial state of the enterprise." ${ }^{34}$

The Law on Enterprises eventually recognized the need to discharge the debt of the enterprise after a bankruptcy, but the Russian Law on Enterprises reverted back to the socialist principle that employee compensation contracts must be fulfilled regardless of the financial situation of the enterprise. Although western bankruptcy proceedings frequently designate the employees as privileged creditors, they provide that in the case where the debtor is unable to meet such contractual obligations, these may be discharged.

\section{The Search for a Comprehensive Bankruptcy Law}

\section{Maturing Need for New Bankruptcy Legislation}

Facing the continuing unraveling of the Soviet economy, many economists and law-makers believed that the above legislation was insufficient and that more comprehensive bankruptcy legislation would be required to help stabilize the move toward a market-based economy. One commentator noted in 1990 that within the Soviet government, "there is a general belief that many of the newly created private and mixed enterprises will fail and that if and when that happens there will be a need to protect the interests of the creditors of such insolvent organizations." 45 At that time, the Soviet Union was conducting a study of bankruptcy laws in leading commercial nations, and it was anticipated that a new bankruptcy law might be passed as early as the end of $1990 . .^{46}$ Yet, strong political and ideological opposition to Gorbachev's key economic legislation delayed the formulation of any comprehensive bankruptcy law until after the dissolution of the Soviet Union.

During the first year after the dissolution of the Soviet Union, the economic crisis in Russia showed no signs of improving. In an April 1992 interview with Komsomol'skaia pravda, the Russian Minister of Economics,

43. Law on Enterprises, supra note 6, art. 39, sec. 3, at 83.

44. Russian Law on Enterprises, supra note 8, art. 17, at 191.

45. Osakwe, supra note 2, at 12-9.

46. Id. 
Andrei Nechaev, argued that the deepening economic crisis in Russia would require new thinking and a greater understanding of a market-based economy. ${ }^{47}$ Asked if this could only occur after a general economic collapse, Nechaev responded, "Why should we wait for a general collapse? It should be enough to arrange ten different instructive bankruptcies. So that producers will finally realize that it is better to lower prices and slightly diminish the appetite ... than to be left with empty hands." ${ }^{248} \mathrm{He}$ added that this was unlikely, however, as there was no bankruptcy law in Russia. ${ }^{49}$

By this time, though, other Russian officials were becoming increasingly aware of the problem of bankrupt enterprises. At the end of May 1992, Georgii Matiukhin, Chairman of the Russian Central Bank, warned Parliament that within three months the reciprocal debts of enterprises could reach two million rubles, but that figure was reached barely a month later. ${ }^{50}$ In a 2 July 1992 interview concerning the economic crisis in Russia, S. Nikitin, Deputy Chief Accountant of the Russian Central Bank declared that "those enterprises which are running at a loss - that is, enterprises which are making goods which are not in demand - can be declared bankrupt." ${ }^{\text {1 } 1}$ He suggested issuing stock as a means to attract resources and escape bankruptcy. ${ }^{52}$

Spurred on by such forecasts, the Russian Parliament began to debate a law on bankruptcy, continuing the search for a comprehensive bankruptcy law begun under the previous regime. President El'tsin preempted the development of this legislation on 14 June 1992 by issuing an edict on "Measures for Support and Restructuring of Insolvent State Enterprises (Bankrupts) with Application of Special Procedures." 33

\section{The Interim Edict on Insolvent State Enterprises}

El'tsin's Presidential edict, despite its limited application to state enterprises, marked the first attempt to implement a comprehensive bankruptcy law since the beginning of the move to a market-based economy.

The edict set forth a detailed definition of bankruptcy:

47. I. Savvateyeva, "We Don't Need Great Upheavals: 10 Instructive Bankruptcies Will be Enough", 15 The Current Digest of the Post-Soviet Press 13 (1992) translating from Komsomol 'skaia pravda 2 (9 April 1992).

48. Id.

49. Id.

50. "Bank Official Comments on Enterprise Debts", Foreign Broadcast Information Service 58 (9 July 1992), translating Moscow Russian Television Network, 1900 GMT, 2 July 1992.

51. Id.

52. Id.

53. Measures for Support and Restructuring of Insolvent State Enterprises (Bankrupts) with Application of Special Procedures, Russian Federation President's Edict No.623 (14 June 1992) (WESTLAW, Rus.Legis.) [hereinafter Presidential Edict]. 
nonfulfillment for three months of state budget obligations, failure to satisfy creditor claims within three months of maturity, and debt amounting to twice the enterprise's assets. ${ }^{54}$

Bankruptcy determinations were to be made by the committee for property management from the state agency owning the enterprise, ${ }^{55}$ with the possibility that creditors or the enterprise itself could request that the committee examine the possibility of declaring bankruptcy. ${ }^{56} \mathrm{~A}$ determination would be rendered within one month after opening bankruptcy proceedings as to whether the state enterprise was deemed solvent or bankrupt. ${ }^{57}$

If financially possible, the committee was required to adopt a program for restructuring the state enterprise..$^{58}$ The actual restructuring (reorganization) would be directed by an "independent entrepreneur" selected through competitive bidding, and given six to eighteen months to restore solvency to the enterprise. ${ }^{59}$ This bidding process would be open to foreign entrepreneurs. ${ }^{60}$

Although the reorganization authority would be given all rights to administer the enterprise, including appointment or discharge of employees, and the right to dispose of assets, ${ }^{61}$ the edict placed a number of potentially untenable constraints on any such reorganization. The reorganization authority was required to retain seventy percent of the work force, guarantee social protection for employees, "including mandatory assurance of redundant employees of their rights and interests." 62

If the reorganization authority was successful in its attempts to restore financial health to the state enterprise, as determined by the state committee, the state of bankruptcy would be terminated, ${ }^{63}$ and the entrepreneur became the new owner of the enterprise..$^{64}$ If the enterprise was not financially viable, or was declared bankrupt again within one year of the reorganization, the

54. Id. at sec. 2. It is unclear from the text whether a debtor must satisfy all three or just one of these criteria to be considered bankrupt.

55. Id. at sec. 3 .

56. Id. at sec. 4.

57. Id. at sec. 7 .

58. $I d$. at sec. 10 .

59. Id. at sec. 11 .

60. Id.

61. Id. at sec. 14 .

62. Id. The edict also required the repayment of debt, and the protection of ecological safety during restructuring. $I d$.

63. Id. at sec. 19.

64. Id. at sec. 20. It is unclear from the text of the edict whether the entrepreneur must purchase the enterprise, or whether the entrepreneur is entitled to the enterprise as payment for the service of restoring the enterprise to solvency. If the entrepreneur is required to infuse capital into the enterprise as part of the reorganization, then this would be considered a bailout proceeding. 
property committee would liquidate the enterprise, ${ }^{65}$ with the control over the enterprise and its assets passing to the property committee ${ }^{66}$ At this point, the property committee was required to liquidate the enterprise and prepare the enterprise and/or its assets for sale. ${ }^{67}$

Bidders for the enterprise were required to purchase the enterprise in its entirety, accept the obligations of the enterprise, and commit to ensure the social guarantees, rights and interests of the enterprise employees ${ }^{68}$ Bidders were also required to maintain the core activity of the enterprise, and retain seventy percent of the work force ${ }^{69}$ If the enterprise was not purchased in its entirety, its assets were to be offered for sale individually. ${ }^{70}$

Notably, the edict did not address the issue of creditors' rights. Although creditors had the opportunity to request that the property committee consider bankruptcy, they did not have a right to formally initiate bankruptcy proceedings independently of the property committee. Similarly, the edict made no provision for participation of the creditors in the process of determining the bankruptcy, reorganization, or the liquidation of the enterprise. " And, probably most important, the edict did not provide for a priority amongst the creditors, but rather provided a general listing of how the proceeds from any liquidation were to be distributed. ${ }^{72}$

The second major flaw of the edict is that it did not provide for an independent body to determine the financial state of the enterprise. State property committees were unlikely to declare an enterprise bankrupt, since doing so would lead to the consequence of either the enterprise being liquidated or transferred to the ownership of a private entrepreneur. In either case, the state agency would lose control over the enterprise.

Despite these weaknesses, the Presidential edict was welcomed by the Minister of Economics as a legal basis for beginning the process of liquidating unprofitable state enterprises. ${ }^{73}$ The Minister emphasized that the edict should serve as a warning to Russian businessmen and executives so they would realize the extent of their personal financial responsibility for the

65. Id. at sec. 22.

66. Id. at sec. 23.

67. Id.

68. Id. at sec. 24 .

69. Id.

70. Id.

71. The edict does provide creditors with a two-month time frame to file claims after the property committee determines to liquidate an enterprise. Id. at sec. 23.

72. This listing includes obligations to the budget, claims of creditors, redundancy payments to enterprise employees, and "other mandatory payments." Id. at sec. 25.

73. "About the President's Decree on Bankruptcy", 24 The Current Digest of the Post-Soviet Press 11 (1992) translating Rossiiskie vesti (19 June 1992). 
problem of nonpayment of debt. ${ }^{74}$ However, despite the proclamation of the edict, the problem of enterprise bankruptcy continued to steadily grow. On 19 November 1992 the Russian Parliament responded to this looming crisis and enacted the Russian Federation Insolvency (Bankruptcy) of Enterprises Act. $^{75}$

\section{Adoption of the Insolvency (Bankruptcy) of Enterprises Act}

The Insolvency (Bankruptcy) of Enterprises Act (hereinafter the Insolvency Act) aspires to establish the legal basis for reorganization of bankrupt enterprises, and voluntary or involuntary liquidation of bankrupt enterprises where reorganization measures are economically infeasible or have proved unsuccessful. ${ }^{76}$ The Insolvency Act attempts to achieve this goal particularly by both establishing the preconditions and procedures for determining bankruptcy and establishing the order of priority for the payment of creditors' claims. ${ }^{77}$

\section{The Insolvency Act and the Five Functions of a Bankruptcy Code}

The Insolvency Act specifically addresses all five functions of a bankruptcy code in its attempt to create a comprehensive system of bankruptcy.

1) Defining bankruptcy. The Insolvency Act provides that an enterprise, state or private, may be deemed bankrupt upon a determination that it is incapable of meeting creditors' claims to payment for goods or services, including statutorily required payments into the budget and "off-budget funds," as a result of the debtor's obligations being in excess of its assets, or

74. Id. Not all commentators accepted the premise that substantial numbers of Russian enterprises were poised for bankruptcy. Russia's Deputy Prime Minister Anatolii Chubais claimed that approximately ten to twenty percent of Russian enterprises were bankrupt, not the eighty percent figure proposed by some. "Denies 80 Percent of Enterprises Bankrupt", Foreign Broadcast Information Service 17 (17 November 1992) translating Moscow Interfax, 1332 GMT, (15 November 1992) [hereinafter "Denies Enterprises Bankrupt"]. Although accepting the possibility that some bankrupt enterprises existed, the Deputy Prime Minister minimized their significance, stating that "Russia will have to face the possibility that newly privatized enterprises will go bankrupt. However, this will pose no tragedy for the stockholders, because if the worst comes to worst, they'll still own the property of their enterprises, which they can sell and receive a dividend in this way." Id.

75. Russian Federation Insolvency (Bankruptcy) of Enterprises Act, Russian Federation Act No.3929-1, Russian Federation Supreme Soviet Decree No.3930-1, (19 November 1992) (WESTLAW, Rus. Legis.) [hereinafter Insolvency Act].

76. Id.

77. Maria Kuzmenkova, "Bankruptcy Law for Enterprises Approved", Moscow ITAR-TASS, 1355 GMT (12 November 1992) translated in Foreign Broadcast Information Service 27 (17 November 1992). 
as a result of an "unsatisfactory structure of the debtor's balance sheet."78 The objective indication of bankruptcy is the suspension of payments to creditors for a period of three months. ${ }^{79}$

This definition of bankruptcy combines the two indicia of insolvency, non-payment of debt and debt in excess of assets, to require a fairly high threshold for the declaration of bankruptcy. Although the Act retains some of the ambiguity of previous acts by referring to the condition of "unsatisfactory structure of the debtor's balance sheet" as a possible basis upon which to determine bankruptcy, the act does provide the objective standard of a suspension of payments to creditors for a period of three months. This latter criteria will likely be the most actively used basis for initiating bankruptcy proceedings.

2) Determining insolvency. Unlike previous legislation, the Insolvency Act provides that an enterprise may be declared bankrupt either voluntarily or involuntarily by a court of arbitration..$^{80}$ The determination of insolvency may be sought either by the debtor enterprise, or the creditor(s).$^{81}$ The debtor enterprise may file a request for a determination of insolvency and subsequent voluntary liquidation of its assets.$^{82}$ Once the debtor has filed such a petition, it may not be revoked. ${ }^{83} \mathrm{~A}$ creditor of the enterprise may after nonpayment of debt for three months, and after service of notice requesting payment, file a petition for determination of bankruptcy and reorganization of the enterprise. ${ }^{84}$ The creditor may not at first seek liquidation of the enterprise. ${ }^{85}$ The creditor may revoke its petition prior to the commencement of bankruptcy proceedings. ${ }^{86}$

Once a petition has been filed, the arbitration court shall conduct a hearing to determine whether the enterprise is indeed bankrupt. ${ }^{87}$ The court is required to consider evidence and opinions from the debtor enterprise, local financial agency, banks providing settlement and credit services to the debtor, creditors, and representatives of the enterprise's work collective. ${ }^{88}$

78. Insolvency Act, supra note 75, art. 1.

79. Id.

80. Id. art. 1.

81. Id. art. 4. The procurator may also file a petition for bankruptcy in cases of fraudulent or fictitious bankruptcy. $I d$. art. 7 , sec. 1 .

82. Id. art. 4 , secs. $1 \& 2$.

83. Id. art. 4, sec. 6 . The rational for this requirement being that a debtor could forestall payment of debt by frequently filing and then withdrawing petitions for bankruptcy.

84. Id. art. 6 , sec. 1 .

85. Id.

86. The rational being that the creditor may successfully use the threat of bankruptcy proceedings to acquire payment of debt.

87. Id. art. 10 , sec. 1 .

88. Id. 
The court shall then determine the enterprise to be either solvent and dismiss the suit, or insolvent and initiate bankruptcy proceedings. ${ }^{89}$

By providing a specific procedure for the filing of bankruptcy petitions and the adjudication of such petitions, the Insolvency Act creates a clear and identifiable process for seeking determinations of bankruptcy. The existence of this open process will facilitate the ability of debtors and creditors to utilize the bankruptcy process, and thereby encourage use of the bankruptcy system.

3) Establishing a process for reorganization or liquidation. After a determination of bankruptcy, the court may initiate either a reorganization or a liquidation. Reorganization may be either in the form of receivership or bailout. The court may also confirm a composition.

The court is permitted to initiate a receivership only if there is a "real possibility of recovery of solvency by debtor." Upon making this determination, the court appoints a receiver to take control of the operation and assets of the enterprise, ${ }^{91}$ with the purpose of restoring solvency through the sale of part of its assets and any other organizational and economic measures necessary. ${ }^{92}$ The period of receivership lasts for a maximum period of eighteen months, ${ }^{93}$ during which time a moratorium is placed on all creditor claims against the debtor. ${ }^{94}$ If the owner of the enterprise or its creditors believe the operation of the enterprise by the receiver harms their interests, they may petition the court to review the receiver's operational plan. ${ }^{95}$

At such time as appropriate, but within eighteen months, the receiver either informs the court that the enterprise has been restored to solvency or that it is not possible to restore the enterprise to solvency. ${ }^{96}$ The court may

89. Id. art. 10 , sec. 2 .

90. Id. art. 12, sec. 2 .

91. Id. art. 12, sec. 4 . The receiver must be an economist or a lawyer, or must have business experience and no criminal record. Id.

92. Id. art. 12 , sec. 2 . The receiver shall have the authority to operate as senior executive of the enterprise; dismiss other senior executives; lay off personnel, in accordance with Russian labor legislation; dispose of assets; convene creditors' meetings; and draft and implement a plan for returning the enterprise to solvency. $I d$. art. 12 , sec. 6 . The receiver is not constrained by obligations to retain a specific percentage of the work force, or to ensure continuation of social benefits, as was the case with the El'tsin Presidential edict. See supra note 53 , and accompanying text.

93. Insolvency Act, supra note 75, art. 12, sec. 2.

94. Id. art. 12, sec. 3 .

95. Id. art. 12, sec. 10.

96. Id. art. 12, sec. 11 . 
then terminate receivership (if solvent), ${ }^{97}$ or initiate liquidation proceedings. ${ }^{98}$

As with receivership, a bailout is permitted only after the court has determined that there is a real possibility the enterprise can be made solvent through the extension of financial assistance. ${ }^{99}$ The owner of the debtor enterprise, creditors, and members of the enterprise's work collective have the priority right to perform the bailout of the enterprise. ${ }^{100}$

Once an offer to bail out the enterprise has been tendered, participants in the bailout must work out an agreement providing for payment of creditor claims by specific deadlines, ${ }^{101}$ but no later than eighteen months. ${ }^{102}$ Participants in the bailout are held jointly and severally liable for the debt of the enterprise, unless provided otherwise in the agreement. ${ }^{103}$ The court then approves the bailout agreement, and the bailout will commence. ${ }^{104}$ If during the course of the bailout, the owner of the enterprise or its creditors believe the bailout is ineffective or harms their interests, they may petition the court to review the operation of the bailout. ${ }^{105}$ The court may then terminate the bailout or render any appropriate decisions. ${ }^{106}$

At such time as is appropriate, but no later than the prescribed eighteen months, the court may declare the bailout successful and terminate the bankruptcy proceedings, or the court may declare the bailout ineffective and render a decision on the solvency of the debtor, which will then likely lead to liquidation proceedings. ${ }^{107}$

The purpose of liquidation proceedings is the "proportional satisfaction of creditors' claims and discharge of debtor from debt, and also the ... protection [of] the parties from wrongful acts with respect to each other."'108

97. Although the Insolvency Act does not indicate the disposition of the enterprise after termination of receivership, it appears the intent is to return the management and ownership of the enterprise back to the original owners. This differs significantly from the El'tsin edict where the receiver was granted ownership of the state enterprise after restoring solvency.

98. Id. art. 12 , sec. 10 .

99. Id. art. 13, sec. 2.

100. Id. art. 13, sec. 1. If the priority bailors do not exercise their right, the bailout will be open to all legal persons, including foreign persons. Id. art. 13, sec. 4.

101.Id. art. 13, sec. 7. The agreement must provide that not later than twelve months past the commencement of the bailout, forty percent of the total claims of the creditors must be met. Id.

102.Id. art. 13 , sec. 9.

103.Id. art. 13, sec. 7 .

104. Id. art. 13, sec. 8 .

105.Id. art. 13 , sec. 10

106.Id.

107.Id. art. 13, secs. $11 \& 12$.

108.Id. art. 15. 
The court initiates liquidation proceedings in the event a debtor requests liquidation, or is deemed insolvent and recourse to receivership or bailout has not been successful.

Upon commencement of liquidation proceedings, all debt payments are suspended, and all debt obligations matured. ${ }^{109}$ The court then appoints a bankruptcy trustee ${ }^{110}$ who collects, values, ${ }^{11}$ and takes legal title, in trust, to the assets of the enterprise, ${ }^{112}$ and recognizes or rejects creditors' claims. ${ }^{113}$ The trustee then liquidates the assets through the formation of a liquidation committee. ${ }^{114}$ From the revenue generated through liquidation, the trustee pays the claims of the creditors in the priority specified in the Insolvency Act. ${ }^{115}$ Any objections to the activities of the trustee, including the payment of creditors' claims may be adjudicated by the court. ${ }^{116}$

At any stage of the bankruptcy proceedings, the parties may agree to a composition and submit it to the court for approval. ${ }^{117}$ The composition will be approved if it is supported by two-thirds of the creditors in value, ${ }^{118}$ and where the composition does not create conditions unfavorable to those creditors opposing composition. ${ }^{119}$ Within two weeks of confirmation of composition by the court, the creditors must receive at least thirty-five percent satisfaction of their exposure to the debtor. ${ }^{120}$ The composition may be rescinded at any time, either by agreement of the parties or by ruling of the court, in instances where the composition is not executed, the financial condition of the debtor continues to deteriorate, or where the debtor has infringed upon the creditors' rights and legitimate interests. ${ }^{121}$ If the composition is rescinded, the matter is returned to the bankruptcy proceedings, ${ }^{122}$ and the claims of creditors are renewed. ${ }^{123}$

The Insolvency Act overcomes the deficiencies of the earlier attempts at a bankruptcy code by providing a detailed and fair process for reorganiza-

109.Id. art. 18.

110. The senior executives of the enterprise shall be dismissed, and the trustee shall assume their authority. Id. art. 24.

111. Id. art. 26, sec. 2.

112. These assets shall not include housing stock, child-welfare institutions, and infrastructure facilities vital to the community. Id. art. 26 , sec. 1.

113.ld. art. 21 , sec. 1.

114. Id. art. 21, sec. 1; and art. 34 .

115. See infra note 136 and accompanying text.

116. Insolvency Act, supra note 75, art. 31.

117.Id. art. 39; and art. 41 , sec. 2.

118.Id. art. 41 , sec. 2.

119.Id. art. 40 , sec. 2.

120.Id. art. 42 , sec. 4.

121.Id. art. 43 , sec. 2.

122.Id. art. 43, sec. 2.

123.Id. art. 43 , sec. 4. 
tion, liquidation, or composition. The one potential flaw in this process, however, is the appointment of a receiver in the case of reorganization. Because the Insolvency Act does not provide for a reorganization controlled by the owner, two distinct problems may arise. First, the owner will be less likely to invoke voluntary bankruptcy proceedings as this will entail relinquishing control of the enterprise for up to eighteen months. Secondly, the Act assumes the enterprise is in bankruptcy because of mismanagement, whereas the cause might be a general economic decline, or the accidental accumulation of excessive debt. In this event, the owner is likely to be in as good, or better, a position to reorganize the enterprise and restore solvency.

4) Establishing creditors ' rights and priority. The Insolvency Act establishes a number of avenues for creditors to protect their interests during the bankruptcy proceedings, and establishes a detailed priority for the payment of creditor claims.

In all bankruptcy proceedings the debtor is required to file specific information with the court which is necessary for creditors in order to protect their interests. This information includes: the total amount of unsatisfied claims, the assets of the enterprise, current balance sheet (including payables and receivables), and the reason for the inability to meet creditors' claims. ${ }^{124}$

In cases of reorganization, creditors are entitled to propose nominees for receiver, ${ }^{125}$ determine the compensation of the receiver, ${ }^{126}$ form a creditors' committee with the power to request information from the receiver, and confirm or amend the plan for official receivership. ${ }^{127}$ In the case of bailout proceedings, as discussed above, the creditors are entitled to a priority option to participate in the bailout, ${ }^{128}$ and are entitled to have their claims paid in full. ${ }^{129}$

In cases of liquidation, creditors are entitled: to preservation of the debtors assets by prohibiting the sale of those assets after commencement of the liquidation proceedings, ${ }^{130}$ to form a creditors' committee with the right to make nominations for the bankruptcy trustee; determine the trustee's compensation; authorize the trustee to dispose of the debtors' assets; and approve any compositions. ${ }^{131}$ In the event a creditor's claim is rejected by the

124.Id. art. 5 , secs. $2 \& 3$.

125.Id. art. 12 , sec. 4 .

126.Id. art. 12, sec. 5 .

127.Id. art. 12, secs. 7, 8, \& 9. Representatives of the enterprise's work collective are permitted to attend creditor committee meetings. Id. art. 12, sec. 9.

128.Id. art. 13, sec. 1 .

129.Id. art. 13 , sec. 7 .

130.Id. art. 18.

131.Id. art. $23, \mathrm{sec} .2$. In the event of a composition, individual debtors, whether or not they voted in favor of the composition, may object to the composition before the court. Id. art. 42 , sec. 3 . 
trustee, the creditor may petition the court to review this rejection. ${ }^{132}$ Through the trustee, the creditors may seek to have payments made to other creditors six months prior to the initiation of bankruptcy proceedings declared null and void and returned to the assets of the enterprise, if those payments were made at a time when the enterprise was effectively insolvent. ${ }^{133}$

In order to protect creditors from wrongful acts of the debtor, the Insolvency Act provides that it shall be illegal to: 1) create a fraudulent or fictitious bankruptcy; ${ }^{134}$ 2) conceal assets or obligations, make false entries in bookkeeping documents, or alienate property purchased on credit in anticipation of bankruptcy proceedings; or 3) conceal from the trustee information regarding previous transfer of enterprise assets, valuation of assets, and location and control of assets, after bankruptcy proceedings have begun. ${ }^{135}$

The Insolvency Act establishes a priority for claims along the following lines: 1) expenses incidental to the bankruptcy proceedings, 2) personal injury claims, 3) a) claims for labor remuneration, including pension fund and benefit payments, and b) copyright and licensing fees, 4) mandatory payments into budget and off-budget funds, 5) standard creditor claims, 6) claims of work collectives with an ownership interest in the enterprise, 7) claims of other owners, and 8) all other claims. ${ }^{136}$ Claims for each order of priority shall be fully satisfied before claims of the next priority are paid. ${ }^{137}$ In the event assets are not sufficient to satisfy the claims of all the creditors in a given category, the claims will be satisfied in proportion to the sum due to each of the creditors. ${ }^{138}$

The Insolvency Act represents a substantial success for creditors. The detailed articulation of creditors' rights and priority suffers from only a few minor defects. Though the Act attempts to prohibit wrongful acts on the part of the debtor, these acts are punishable as criminal offenses, but do constitute a ground for denying the discharge of the debtor's debt obligations. Although

132.Id. art. 27. The creditor may also petition the court to review a determination of the priority of a creditor's claim. Id.

133.Id. art. 28. If the payments where made with the intention of causing loss to other creditors, and the receiving creditors were aware of this action, the payments may be declared null and void regardless of the six-month time frame. Id.

134. A fraudulent bankruptcy is defined as the "deliberate creation or increase of insolvency of enterprise by executive or owner, infliction of loss on enterprise for personal gain or for the gain of other persons, or deliberately incompetent management of business." Id. preamble. A fictitious bankruptcy is defined as the "deliberately false announcement of insolvency by enterprise with the aim of misleading creditors to obtain postponement and/or deferment of payments due to creditors, or reduction of debt." Id.

135.Id. arts. $44,45, \& 46$.

136.Id. art. 30 , sec. 2.

137.Id. art. 30 , sec. 3 .

138. Id. art. 30 , sec. 4 . 
in some instances a credible threat of criminal liability may be a sufficient deterrent from wrongful acts, it is located outside of the bankruptcy proceedings, and not available as a tool for the creditor to prompt full and fair disclosure of assets. Denial of discharge would provide the creditors with the necessary leverage.

The listing of creditors is comprehensive and fair, but fails to establish limits on the amounts which may be sought under priority claims. For instance, by failing to place a limit on the amount of employee compensation, owners or executives may circumvent the rights of creditors by paying out substantially all of the proceeds to top executives as employee compensation. Additionally, there are no penalties for tardy filing by creditors, and there is no provision for equitable subordination of creditor claims.

5) Discharging debt obligations. Recognizing the need to provide debtors with a clean slate to begin business anew, the Insolvency Act provides both that creditors' claims not satisfied for lack of enterprise assets will be deemed discharged, ${ }^{139}$ and that the debtor will be deemed fully released from further liability for those debt obligations settled within the bankruptcy proceedings. ${ }^{140}$ Additionally, at the time liquidation proceedings commence, the accrual of all penalty and interest payments will be terminated, and any claims on the property of the debtor must be made within the liquidation proceedings. ${ }^{141}$

The debt discharge provisions of the Insolvency Act are sufficient to encourage debtors to seek voluntary bankruptcy proceedings and to ensure that debtors will be able to start an enterprise anew without the continuation of cumbersome debt obligations.

Prospects for the Effective Utilization of the Insolvency Act The enactment of the Insolvency Act has established a firm basis for the functioning of an efficient bankruptcy system in Russia. The adoption of the Insolvency Act is, however, only the first step in the successful utilization of bankruptcy to facilitate the effective operation of a market-based economy in Russia. A number of obstacles must be overcome before the Russian bankruptcy system will be fully operable. These obstacles include: the creation of a reservoir of trained individuals to arbitrate claims of bankruptcy, administer bankrupt companies, and liquidate assets; ${ }^{142}$ the enact-

139. Id. art. 35 , sec. 3 .

140.Id. art. 36.

141. Id. art. 18.

142. J. Rotowski, "The Inter-enterprise Debt Explosion in the Former Soviet Union: Causes, Consequences, Cures", 5 Communist Economies \& Economic Transformation 1993, $135,155$. 
ment of a number of necessary accompanying acts, such as statutes on price indexation, and the indexation of the value of the property of enterprises; ${ }^{143}$ and alleviation of the public fear and misconception concerning bankruptcies.

Recognizing these obstacles, the Russian government has already made substantial progress in creating the necessary support for an effective bankruptcy system. In order to create the necessary reservoir of trained experts, the Supreme Soviet decree enacting the bankruptcy law directed the government to establish a system for training official receivers and bankruptcy trustees from among experienced business managers and qualified lawyers and economists, and to draft a statute creating a federal agency for bankruptcy affairs. ${ }^{144}$ In response to this decree, on 27 November 1992 the Supreme Soviet issued a new decree strengthening the arbitration courts. Its provisions included the budgeting for official trips of arbitration court judges to study "the practice of bankruptcy cases and the resolution of economic disputes" abroad, as well as inviting foreign specialists to Russia to set up training courses. ${ }^{145}$

Attempting to alleviate public fear concerning adoption of the bankruptcy law, the chief consultant to the Higher Court of Arbitration assured business leaders that the court would give preference to reorganization over liquidation of an insolvent enterprise. ${ }^{146}$ Similarly, one of the law's primary drafters asserted that "a wave of bankruptcy is not eminent, especially since mechanisms for supporting and improving enterprises that are necessary to the national economy are to be set in motion."147

With the filing of the first successful Russian bankruptcy in September of 1993 involving the Zvezda knife factory, there is now a model upon which to build future bankruptcy proceedings. ${ }^{148}$ Hopefully the success of the Zvezda reorganization will allay public fears about bankruptcy and encourage both creditors and debtors to seek the economic tool of bankruptcy to facilitate the

143. "Supreme Soviet Discusses Bankruptcy Law, Referendum", Moscow Radio Rossia Network, 1990 GMT (2 February 1993) translated in Foreign Broadcast Information Service at 28 (3 February 1993).

144. Presidential edict, supra note 53, at sec. 3(a).

145. "Decree on Strengthening of Arbitration Courts", Rossiiskaia gazeta at 5 (17 December 1992), translated in Foreign Broadcast Information Service at 28-9 (29 January 1993).

146. Irina Demchenko, "Law on Bankruptcy To Go Into Effect Soon", Izvestiia at 2 (4 Febru147.Id. ary 1993) translated in 5 The Current Digest of the Post-Soviet Press 21 (1993).

148. For a description of the process of filing the Zvezda bankruptcy see "CEELI Helps File First Russian Bankruptcy", Central and East European Law Initiative (CEELI) Update 1 (July-September 1993). 
restructuring of their economic relations on the basis of free market principles. $^{149}$

\section{Conclusion}

The current Russian Insolvency Act represents the result of Russia's gradual recognition of the need for bankruptcy provisions in a market-based economy and reflects the steady evolution of Russian legislation away from the principles of a command economy and toward free market principles. The Insolvency Act is the product of a serious effort on the part of Russian lawmakers to understand the needs of a market-based economy and the interrelationship of the different components of such a system. As such, the Act represents a bankruptcy code that comprehensively addresses the five primary functions of bankruptcy, and thereby establishes a solid basis for an effective bankruptcy system. As Russia continues to experience the pains of transition to a market-based economy, its new bankruptcy system will likely play a key role in increasing enterprise efficiency, protecting creditors' rights, discharging onerous debt obligations, and reallocating limited capital.

149. Unfortunately, in discussing the Zvezda case, A. Kozlov, Director of the Nizhegorod Oblast's Department of Economics and Forecasting, noted that "in the majority of cases, bankruptcy proceedings may end such that managers will be replaced and special-purpose credits will be extended." "Pervoe v Rossii delo o bankrotstve zavoda rassmatrivaetsia $v$ arbitrazhnom sude" (The First Case in Russia of a Factory Bankruptcy is Considered in Arbitration Court), Izvestiia, 27 August 1993, 2. The struggle between the centrallyplanned economy of Russia's communist past and the free market economy it hopes to build continues. For recent reports on the proceedings of the Zvezda reorganization, see Judith Ingram, "Russian Company Tests New Bankruptcy Law", New York Times 50 (25 December 1993); and Elizabeth Rubinfien, "Russia Puts Bankruptcy Law to Work, but First Searches for Best Test Case", Wall Street Journal 11 (12 November 1993). 